\title{
Failure of Teriparatide in Treatment of Bone Complications of Adult Hypophosphatasia
}

\author{
Michel Laroche
}

Received: 21 November 2011/ Accepted: 10 December 2011/Published online: 5 January 2012

(C) Springer Science+Business Media, LLC 2012

\section{To the Editor,}

Some authors have recently reported that teriparatide is effective in the treatment of the bone complications of hypophosphatasia [1, 2]. We report the case of a 43-yearold woman who was treated with teriparatide for 1 year but without effect. Since her childhood, the patient had presented numerous fractures (ribs, pelvis, both femurs) and had migratory arthritis. She was a heterozygous carrier of the N461L mutation in exon 12 of the TNSALP gene. She presented a nondisplaced fracture of the right humeral shaft that was painful and pseudarthrotic in spite of plaster immobilization for 3 months. Treatment was started with teriparatide, $20 \mu \mathrm{g} /$ day. Fifteen days later, the patient required paracetamol for diffuse bone pain. Ten months after treatment was started, teriparatide was discontinued as bone pain had worsened, and in particular, the humeral pseudarthrosis remained unchanged on X-rays and CT scan. Before treatment, corrected serum calcium was $2.47 \mathrm{mmol} / \mathrm{L}$, serum phosphorus $1.32 \mathrm{mmol} / \mathrm{L}$, 24-hour urinary calcium $4.5 \mathrm{mmol} / \mathrm{L}, 25 \mathrm{OHD} 42 \mathrm{ng} / \mathrm{mL}$, parathormone $24 \mathrm{pg} / \mathrm{mL}$, alkaline phosphatase (ALP) $21 \mathrm{IU} / \mathrm{L}$, bone ALP (bALP) $<2 \mathrm{mg} / \mathrm{L}$, osteocalcin $17 \mathrm{ng} / \mathrm{mL}$, and serum CTX $178 \mathrm{pg} / \mathrm{mL}$. At treatment discontinuation, serum calcium was $2.70 \mathrm{mmol} / \mathrm{L}$, serum phosphorus $1.40 \mathrm{mmol} / \mathrm{L}$, 24-hour urinary calcium $6.5 \mathrm{mmol} /$ day, 25OHD $38 \mathrm{ng} / \mathrm{mL}$, PTH $27 \mathrm{pg} / \mathrm{mL}$, ALP $18 \mathrm{IU} / \mathrm{L}$, bALP $<2 \mathrm{mg} / \mathrm{L}$, osteocalcin $43 \mathrm{ng} / \mathrm{mL}$, and serum CTX $560 \mathrm{pg} / \mathrm{mL}$. Spinal bone mineral density (BMD) was

The author has stated that there is no conflict of interest.

M. Laroche $(\bowtie)$

Service de Rhumatologie, CHU Purpan, 1 place du Dr Baylac, TSA 40031, 30159 Toulouse Cedex 09, France

e-mail: laroche.m@chu-toulouse.fr
$1.05 \mathrm{~g} / \mathrm{cm}^{2}$ ( $\mathrm{T}$ score -1.1) and whole-body BMD $0.945 \mathrm{~g} / \mathrm{cm}^{2}$ before treatment (femoral neck BMD could not be measured because of osteosynthesis), while spinal BMD was 1.04 and whole-body BMD was 0.920 after treatment.

In the cases reported in the literature, teriparatide led to increased bALP levels and fracture healing [1-3]. However, although bone remodeling was stimulated in our patient, as shown by increased osteocalcin and CTX, teriparatide did not modify bALP levels or BMD and did not improve fracture healing. It caused marked bone pain and moderately elevated serum calcium.

This is probably related to a different mechanism of decreased ALP activity, depending on the type of mutation: decrease in the quantity of the enzyme, its stability, or its catalytic power. In our patient, the N461L mutation led to complete disappearance of the bone isoenzyme, which was not modified by PTH treatment, whereas the level has been reported to increase in patients presenting the D378V [1] and the G339R, E191K, A176T, and V423A [2] mutations. The solution of the future could be treatment with recombinant ALP [3].

\section{References}

1. Whyte MP, Mumm S, Deal C (2007) Adult hypophosphatasia treated with teriparatide. J Clin Endocrinol Metab 92:1203-1208

2. Schalin-Jäntti C, Mornet E, Lamminen A, Välimaki MJ (2010) Parathyroid hormone replacement improves pain and fracture healing in adult hypophophatasia. J Clin Endocrinol Metab 95:5174-5179

3. Yadav MC, Lemire I, Leonard P, Boileau G, Blond L, Beliveau M, Cory E, Sah RL, Whyte MP, Crine P, Millán JL (2011) Dose response of bone-targeted enzyme replacement for murine hypophosphatasia. Bone 49:250-256 